\title{
Discernimento inaciano: a liberdade humana respondendo a Deus
}

\author{
Orientador: Mario de França Miranda \\ Mestranda: Raisa Suena Soares Lopes \\ Área de Concentração: Teologia Sistemático-Pastoral \\ Linha de Pesquisa: Fé e Cultura
}

O discernimento é uma dimensão intrínseca a vida cristã. No contato com textos bíblicos podemos atestá-la desde os profetas passando por Jesus, Paulo e João. O discernimento nos insere numa vida de fé dinâmica, constantemente interpelada pela ação do Espírito Santo. Essas interpelações devem nos levar a atitudes concretas, onde o ser humano investe sua liberdade no projeto salvífico de Deus. Nessa dissertação propomos uma compreensão dessa realidade a partir da ótica de Inácio de Loyola, o que representa o modo como ele buscou captar e interpretar a vontade de Deus em sua vida e de como este proporciona mais qualidade no seguimento a Jesus Cristo. A marca da sua espiritualidade é o discernimento, o qual é baseado na sua forte experiência de Deus. Inácio enfatiza que Deus se faz ouvir e compreender nos condicionamentos humanos de cada época, nas experiências mais cotidianas; pode ser buscado e encontrado em todas as coisas. Neste panorama, ele resgata a dimensão pessoal da vida cristã, ao mesmo tempo em que proporciona uma unidade antropológica. Pois fala de um estar atento aos movimentos interiores (moções) de consolação e desolação, fazendo disso critério de discernimento. Mais, o discernimento inaciano restaura a liberdade e a responsabilidade na vida cristã, ao admitir que a busca e o encontro da vontade de Deus na vida de cada um cabe à pessoa. Esse traço do discernimento inaciano desemboca numa abertura mais confiante à ação do Espírito Santo e numa vida com mais sentido.

Palavras-chave: Discernimento. Espírito Santo. Inácio de Loyola. 